NASA/TM—2007-214708

(245)

Operational Results From a High Power Alternator Test Bed

Arthur Birchenough

Glenn Research Center, Cleveland, Ohio

David Hervol

Analex Corporation, Brook Park, Ohio 


\section{NASA STI Program . . . in Profile}

Since its founding, NASA has been dedicated to the advancement of aeronautics and space science. The NASA Scientific and Technical Information (STI) program plays a key part in helping NASA maintain this important role.

The NASA STI Program operates under the auspices of the Agency Chief Information Officer. It collects, organizes, provides for archiving, and disseminates NASA's STI. The NASA STI program provides access to the NASA Aeronautics and Space Database and its public interface, the NASA Technical Reports Server, thus providing one of the largest collections of aeronautical and space science STI in the world. Results are published in both non-NASA channels and by NASA in the NASA STI Report Series, which includes the following report types:

- TECHNICAL PUBLICATION. Reports of completed research or a major significant phase of research that present the results of NASA programs and include extensive data or theoretical analysis. Includes compilations of significant scientific and technical data and information deemed to be of continuing reference value. NASA counterpart of peer-reviewed formal professional papers but has less stringent limitations on manuscript length and extent of graphic presentations.

- TECHNICAL MEMORANDUM. Scientific and technical findings that are preliminary or of specialized interest, e.g., quick release reports, working papers, and bibliographies that contain minimal annotation. Does not contain extensive analysis.

- CONTRACTOR REPORT. Scientific and technical findings by NASA-sponsored contractors and grantees.
- CONFERENCE PUBLICATION. Collected papers from scientific and technical conferences, symposia, seminars, or other meetings sponsored or cosponsored by NASA.

- SPECIAL PUBLICATION. Scientific, technical, or historical information from NASA programs, projects, and missions, often concerned with subjects having substantial public interest.

- TECHNICAL TRANSLATION. Englishlanguage translations of foreign scientific and technical material pertinent to NASA's mission.

Specialized services also include creating custom thesauri, building customized databases, organizing and publishing research results.

For more information about the NASA STI program, see the following:

- Access the NASA STI program home page at http://www.sti.nasa.gov

- E-mail your question via the Internet to help@sti.nasa.gov

- Fax your question to the NASA STI Help Desk at 301-621-0134

- Telephone the NASA STI Help Desk at 301-621-0390

- Write to: NASA Center for AeroSpace Information (CASI) 7115 Standard Drive Hanover, MD 21076-1320 
NASA/TM-2007-214708

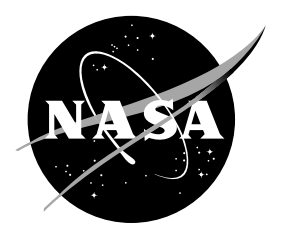

\section{Operational Results From a High Power Alternator Test Bed}

Arthur Birchenough

Glenn Research Center, Cleveland, Ohio

David Hervol

Analex Corporation, Brook Park, Ohio

Prepared for the

Space Technology and Applications International Forum (STAIF-2007)

sponsored by the Institute for Space and Nuclear Power Studies at the University of New Mexico Albuquerque, New Mexico, February 11-15, 2007

National Aeronautics and

Space Administration

Glenn Research Center

Cleveland, Ohio 44135 


\section{Acknowledgments}

The work in this paper was performed for NASA Exploration Systems Mission Directorate and the Prometheus Power and Propulsion Program. The authors would like to thank Vicki Crable, Don Fong, Marcelo Gonzalez, Larry Trase, Mike Chornak, Dave Hausser, and Tom Balogas for their assistance with testing.

Level of Review: This material has been technically reviewed by technical management.

Available from

NASA Center for Aerospace Information 7115 Standard Drive

Hanover, MD 21076-1320
National Technical Information Service 5285 Port Royal Road Springfield, VA 22161

Available electronically at http://gltrs.grc.nasa.gov 


\title{
Operational Results From a High Power Alternator Test Bed
}

\author{
Arthur Birchenough \\ National Aeronautics and Space Administration \\ Glenn Research Center \\ Cleveland, Ohio 44135 \\ David Hervol \\ Analex Corporation \\ Brook Park, Ohio 44142
}

\begin{abstract}
The Alternator Test Unit (ATU) in the Lunar Power System Facility (LPSF) located at the NASA Glenn Research Center (GRC) in Cleveland, Ohio was used to simulate the operating conditions and evaluate the performance of the ATU and its interaction with various LPSF components in accordance with the current Fission Surface Power System (FSPS) requirements. The testing was carried out at the breadboard development level. These results successfully demonstrated excellent ATU power bus characteristics and rectified user load power quality during steady state and transient conditions. Information gained from this work could be used to assist the design and primary power quality considerations for a possible future FSPS. This paper describes the LPSF components and some preliminary test results.
\end{abstract}

\section{Introduction}

Dynamic power systems are being proposed for Lunar and Mars surface power systems. GRC has extensive experience with dynamic power systems dating back to the 1960s. One of the possible high power dynamic conversion system options utilizes a Brayton Power Conversion Unit (BPCU) using a permanent magnet alternator. An operational $2 \mathrm{~kW}$ BPCU test bed has been successfully built and operated at GRC. However, a higher power electrical testbed was desired in order to evaluate the electrical control issues and system performance characteristics at representative conditions for FSPS with multiple independently switched user loads. To meet these needs, the LPSF was developed and built. The two primary objectives of the LPSF were to obtain test data to influence the power conversion design and to assist in developing primary power quality specifications prior to any system design activity. The LPSF contains an ATU, a Main Power Distribution Unit (MPDU), user loads, and an alternator controller using a Parasitic Load Resistor (PLR). Its purpose is to determine the alternator electrical performance, the effectiveness of the parasitic loading based speed and voltage controller, the power quality delivered to the loads, and system responses to transient loading conditions.

\section{LPSF Description}

The ATU is one component of the LPSF that was developed in order to support the various phases of the Prometheus program (Baez et al., 2005). The two primary objectives of the facility were to obtain test data to influence the power conversion design and to assist in developing primary power quality specifications for a possible future FSPS. The LPSF will provide a timely insight of the electrical interactions between a representative permanent magnet generator - the ATU, its associated control schemes, and realistic electric system loads. The main elements of the LPSF are a $50 \mathrm{kWe}$ ATU, an alternator controller using a PLR, a MPDU, and eight user loads. These elements are made of breadboard/brassboard components. The LPSF configuration was developed using readily available offthe-shelf components and use technologies that are applicable to FSPS. A block diagram of the test facility is shown in figure 1. 


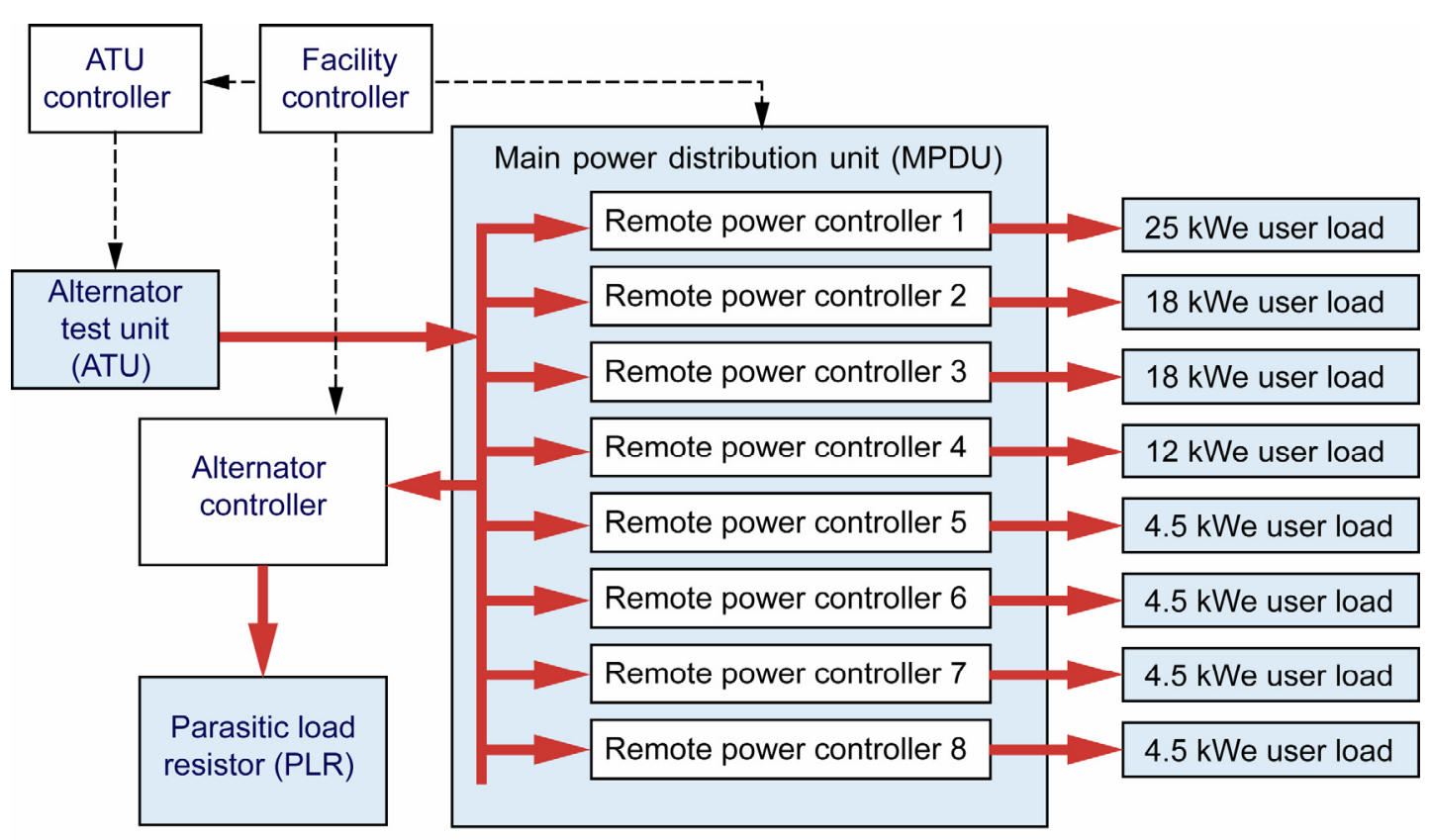

Figure 1.-Overall schematic of the Lunar Power System Facility (LPSF).

\section{Alternator Test Unit}

The ATU is the power supply for the LPSF. It is representative of the style of alternator that would be used on a Brayton dynamic power conversion system. A variable speed 2-pole samarium cobalt permanent magnet brushless motor drives the alternator in place of a Brayton cycle power system. The alternator is a 6-pole permanent magnet alternator utilizing a Halbach array of samarium cobalt magnets. The stator has slots and is fabricated from hiperco 50 laminations that are skewed 1/2 slot to minimize cogging and rotor can losses. The stator windings are paralleled small gauge copper strands to minimize high frequency losses. The ATU was operated to a maximum of $50 \mathrm{~kW}$ three phase power at $400 \mathrm{~V}$ root mean squared (rms) line-to-line. A dedicated control panel allows the unit to be operated in either speed or torque control. Speed control operation senses rotor speed and corrects any deviation by adjusting motor supply current. In torque mode a constant current is commanded for the motor, resulting in nearly constant torque output independent of the motor speed. A pressurized oil loop is included in the ATU assembly. Oil jets are used to lubricate and cool the individual shaft ball bearings and to cool the end turns of the motor and alternator. Additionally, oil passages are used to cool the rotor and stator. This waste heat is transferred through a commercial oil-to-water heat exchanger which is connected to the test facility water supply. The electronic motor drive controls are located in a separate cabinet on a cold plate and are cooled by a stand alone chiller. There is an emergency overspeed shutdown circuit located within the ATU cabinet that trips if the shaft speed exceeds 40,000 rpm. ATU vibration health monitoring is performed with two sets of 3-axis accelerometers mounted on the alternator and motor housing exteriors. The ATU will automatically shutdown should any of the accelerometer readings exceed a predetermined g-level that would indicate an abnormal condition. The drive motor magnet health is monitored by periodically measuring back electromotive force (emf) at shutdown and comparing it to beginning of life test values. The ATU is shown as installed in the LPSF at GRC in figure 2. The oil-to-water heat exchanger, facility water pressure gauge, and oil pressure gauge are visible through the motor/alternator housing window. 


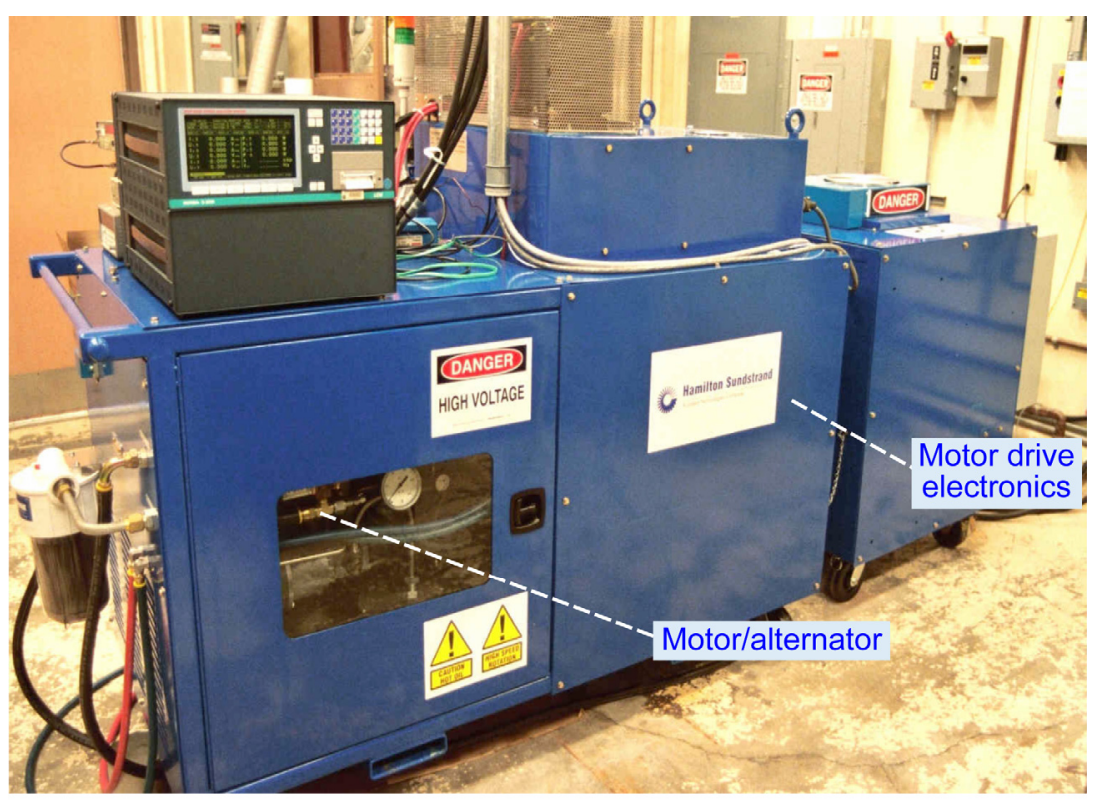

Figure 2.-Overall schematic of the Lunar Power System Facility (LPSF).

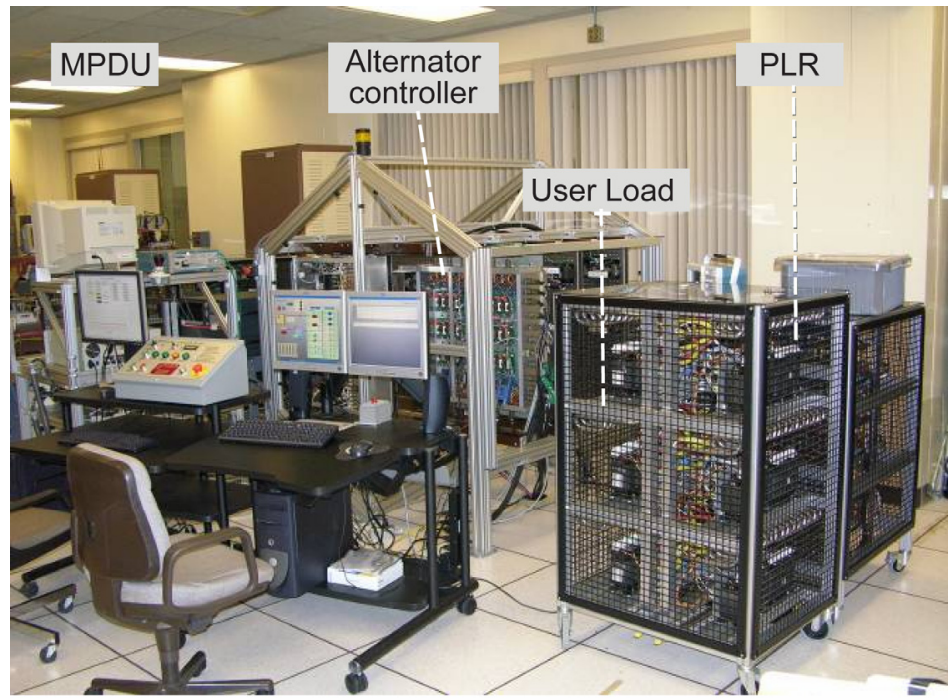

Figure 3.-View of the LPSF control room.

\section{Main Power Distribution Unit}

The location of the MPDU is shown in figure 3. It contains the mechanical relays or contactors that distribute power from the ATU to the user loads and to the parasitic load resistor. The MPDU was sized to handle $50 \mathrm{~kW}$ at $400 \mathrm{VAC}$ line to line rms, 3 phase, $1750 \mathrm{~Hz}$ (corresponding to 35,000 rpm ATU shaft speed). The relays are 3 pole single throw contactors that are de-rated to operate at $400 \mathrm{~V}$ line to line (rms) at a frequency of $1750 \mathrm{~Hz}$. Each of the MPDU relays contain an analog board that implements current and voltage sensing and over-current protection as well as digital circuitry for ON/OFF control, relay status, and programmable set points. The over-current trip setpoint (or 1 p.u. value) for each MPDU relay is programmable through the digital interface. The over-current protection strategy is as follows: $i^{2} t$ tripping for currents higher than 1 p.u. and an instantaneous trip for currents at or above 2 p.u. This 
feature provides the flexibility to use the MPDU relays to feed and protect loads that require currents that are lower than the relay's nominal rating.

\section{Alternator Controller and PLR}

Since the alternator can be operated at either constant speed or torque mode, the function of the alternator controller and PLR is to maintain a constant bus voltage and ATU shaft speed regardless of user loading. This technique of speed and voltage control was first developed for use with the $2 \mathrm{~kW}$ BPCU (Hervol et al., 2003). The alternator control function is based on applying a parasitic load to the alternator output to maintain total load as required for the desired output voltage and/or speed. The alternator controller consists of two main circuits: the power circuits including the parasitic load elements, and the sensing circuits and feedback control loops sending the control signals to the power circuits. The power circuit uses 6-pulse rectification of the power bus in parallel with a separate 6-pulse rectifier using a Wye-Delta transformer to attain a $30^{\circ}$ phase shift. The net effect is a 12-pulse rectification with minimal transformer mass. The parasitic load resistor is connected across the rectified output, in series with a Pulse Wave Modulation (PWM) Field Effect Transistor (FET) switch, through an Electromagnetic Interference (EMI) filter to reduce noise radiated off the parasitic load. In the actual implementation two such resistor/EMI filter/PWM switch segments are connected in series to reduce the voltage requirement of the PWM switch. Additionally, there are 12 such circuits, each having a separate transformer-rectifierparasitic load and PWM switches, in parallel to share the power and provide redundancy. These PWM switches are controlled by two individual sets of 6 time-staggered signals to provide an effective $21 \mathrm{kHz}$ modulation rate.

The sensing and control circuits use a three phase TRMS voltage sensing, alternator speed sensing, and load current sensing as inputs. The basic control loop compares the sensed bus voltage to a reference, and uses a proportional plus integral control function to generate a command to the PWM modulator. Feed forward compensation based on the load current sense is used to speed up the loop response. Additionally, alternator speed is sensed, and the error from the desired speed is used as a trim signal to change the voltage command slightly to run in a constant speed mode if desired. The PWM modulator generates 6 different PWM signals, equal width but phase shifted equally over one half the period of the alternator frequency to reduce waveform distortion. This provides a more steady loading of the alternator.

\section{User Loads}

The main lunar power system loads would be for support of the habitat, communications, and scientific instruments. For the Test Bed these loads will be powered directly from the main distribution bus with a $400 \mathrm{VAC}$ line-to-line 3 phase, $1750 \mathrm{~Hz}$ feed. In order to process AC power, these loads will implement a 3 Phase Transformer-Rectifier that will change the AC voltage level and then rectify and filter to provide DC to the load. The AC load interface will be implemented as 12 pulse transformer rectifiers. The advantage of 12-pulse over 6-pulse rectifiers, besides bus voltage ripple, is maintaining a constant waveshape by standardizing the load configuration. In the LPSF, it is important to represent the electrical behavior (rectification, power factor, harmonics, etc.) of these loads. Therefore, each of these loads will be implemented with its own transformer rectifier unit supplying the required power to a resistive load bank. However, the output voltages for the transformer rectifier units in the LPSF may be different from the voltages that the actual loads will require. For practical purposes, the output voltage of the transformer rectifier units was selected at a value that is suitable and compatible with the Power Systems Facility resistive load bank equipment.

\section{Results and Discussion}

The ATU was first run with a resistive load to determine voltage droop characteristics and the ATU output voltage waveform. The test conditions were $35,000 \mathrm{rpm}$ and up to $50 \mathrm{~kW}$ with the ATU controller 


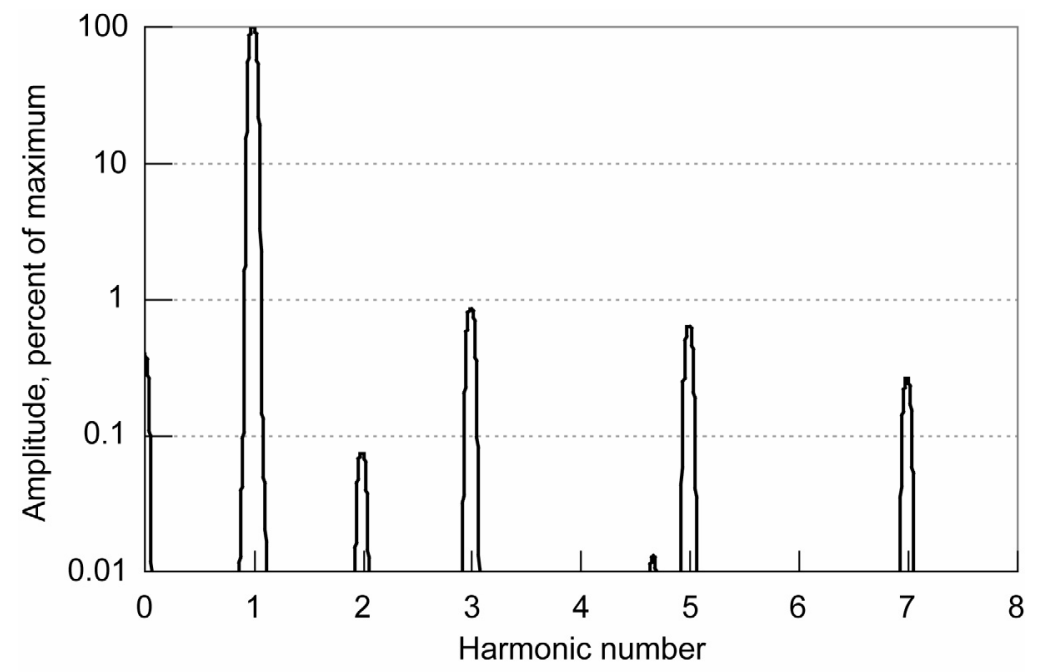

Figure 4.-ATU voltage spectrum with a resistive test load at $50 \mathrm{~kW}$.

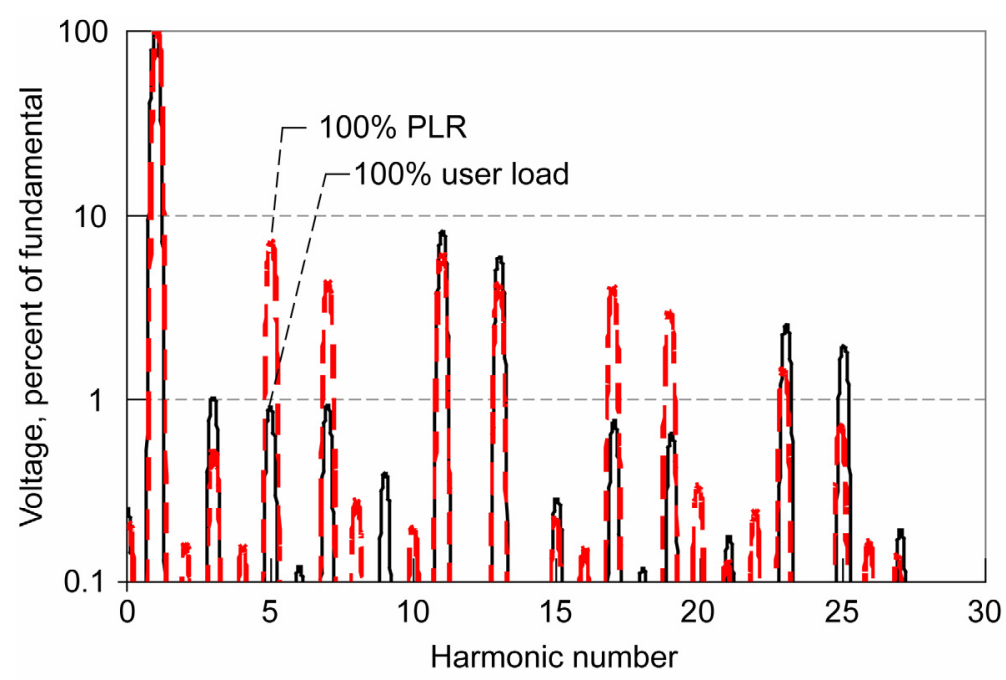

Figure 5._ATU voltage spectrum with a resistive test load at $50 \mathrm{~kW}$.

in speed control. The resulting operating voltage spectrum is shown in figure 4 . The voltages are normalized as percentages of the first fundamental frequency at $1750 \mathrm{~Hz}$. These results show that the maximum higher order harmonic is $<1$ percent with the maximum value at the 3 rd harmonic.

The ATU was then connected to the MPDU and run at $50 \mathrm{~kW}$ and $35000 \mathrm{rpm}$. The user loads and PLR are 12 pulse rectifier loads and therefore have a significant effect upon the ATU output voltage waveform. Two different types of loading conditions were imposed on the ATU; full PLR with no user load and, full user load with no PLR. This was done to highlight any differences between the two loads on the ATU. The frequency spectrum of the AC power bus for both voltage and current are plotted in figures 5 and 6 , respectively.

The results show that the full PLR loading case results in slightly worse harmonics, particularly the 5 th and 7 th harmonics that theoretically should not be present in a 12 pulse system. The cause of these harmonics is unbalance in the PLR transformers. Current spectrum harmonics are lower amplitude than the voltage harmonics due to the inductance of the alternator. Another way to view this is to look at the AC waveform. Figure 7 shows ATU current and voltage waveforms for a 100 percent user load condition. 


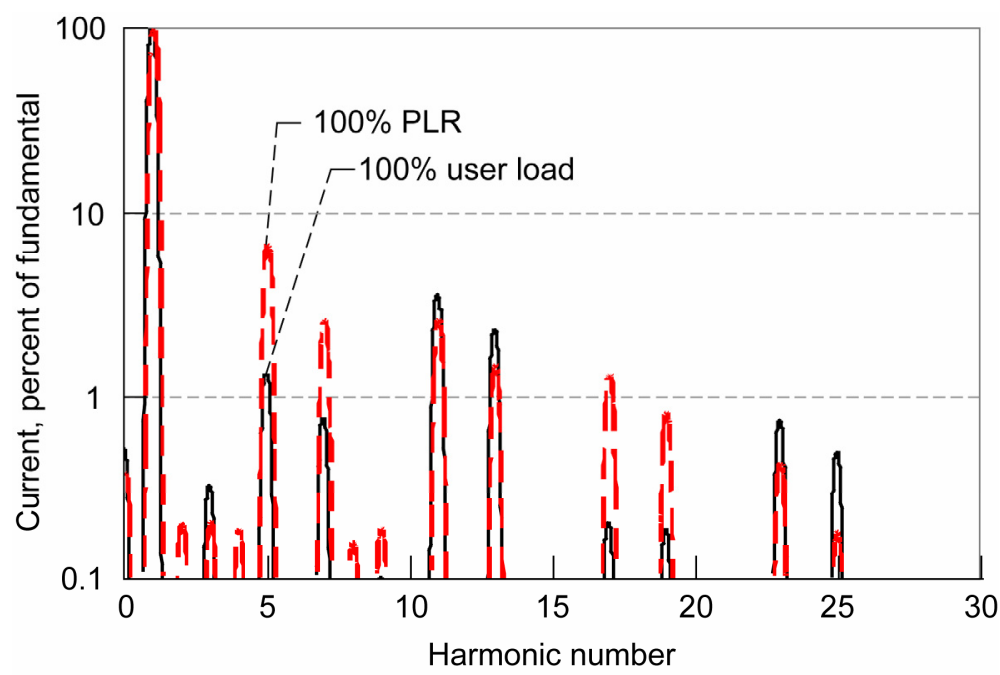

Figure 6.-Harmonic current spectrum at $50 \mathrm{~kW}$ PLR and $50 \mathrm{~kW}$ Load.

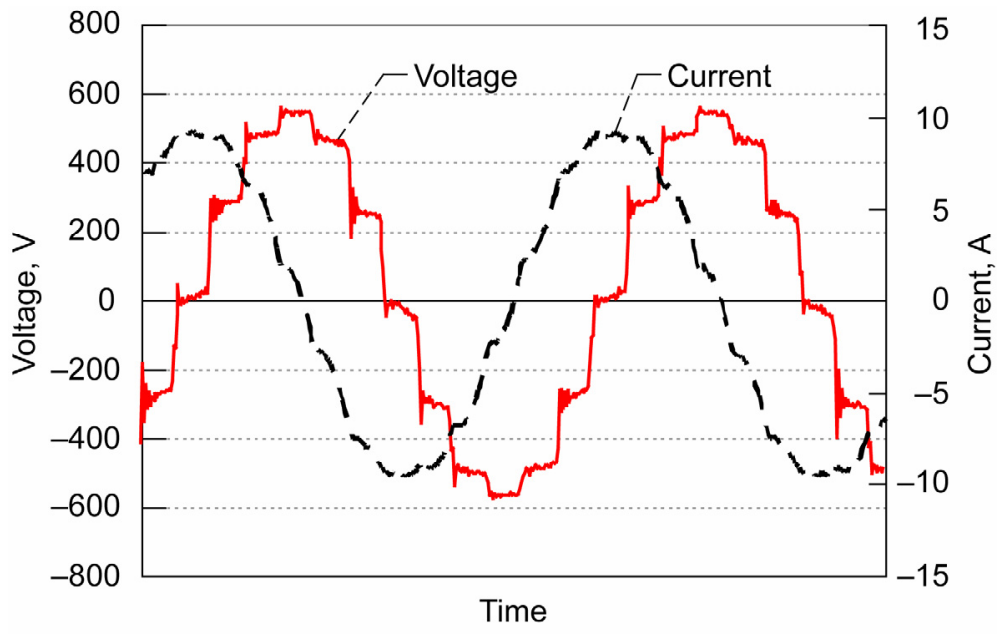

Figure 7.-Voltage and current waveforms for user loads at $1750 \mathrm{~Hz}$.

The influence of the user load 12 pulse rectification is clearly evident in the stepwise appearance of the ATU voltage waveform.

The voltage shown in figure 7 is measured line-to-line whereas the current is the line current, which accounts for the phase shift between these waveforms. The actual power factor measured for this load was 0.97 . This compares favorably to the theoretical 12 pulse system power factor of 0.98 . The difference from the theoretical value can probably be attributed to line and transformer inductance.

Finally, it was important to address the overall power transient response to load application and removal. For this test the ATU was operated on torque control at 35,000 rpm and approximately $50 \mathrm{~kW}$. A small load ( $4.5 \mathrm{~kW}$, load "A") was applied and the motor torque was increased to achieve a relatively high PLR load. A large load (18 kW, load "B") was then switched on and off to observe the effect on the AC bus voltage and load A's DC voltage. Figure 8 shows the bus line to line voltage and rms voltage error in response to a load-on condition. The voltage drop (as shown in the rms voltage error) in the turn on voltage transient is due to the comparatively large inrush current to charge the filter in the load.

Figure 9 shows the equivalent system response to a step load reduction. In this case the voltage overshoots, by only a couple percent, with a slightly faster recovery. 


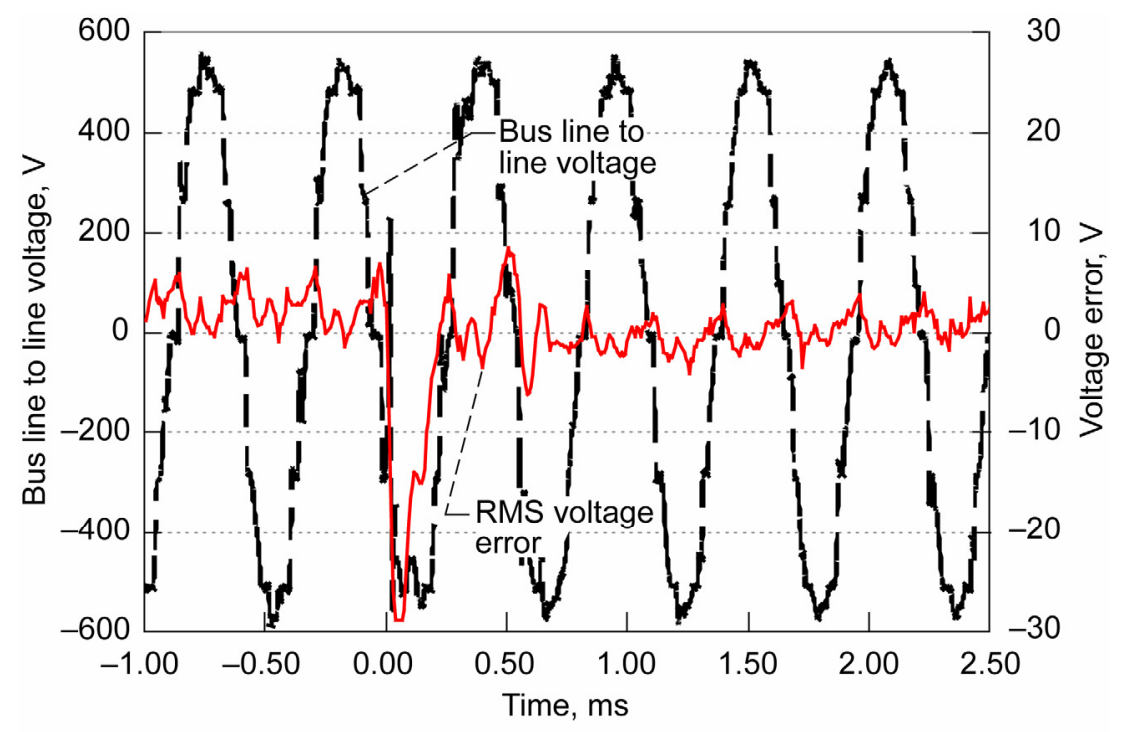

Figure 8.-AC bus line-to-line voltage response to load-on condition.

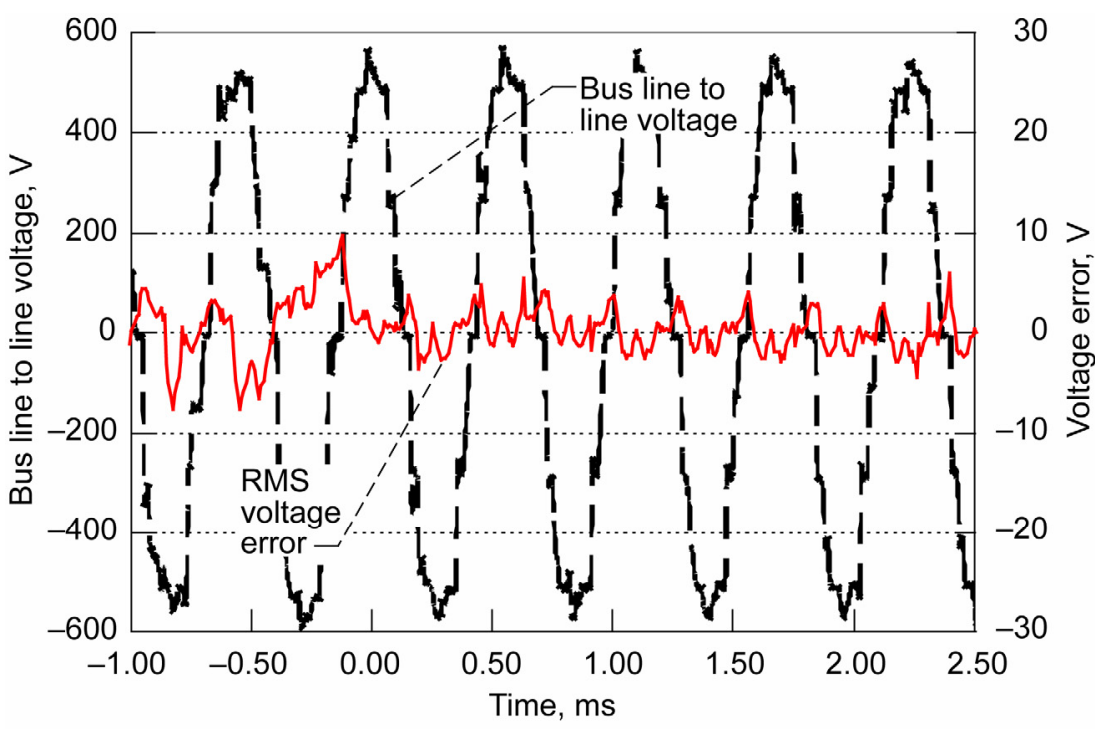

Figure 9.-AC bus line-to-line voltage response to load-off condition.

The variation in load A's rectified DC voltage during the application of load B is shown in figure 10. The inrush current is shown in this figure, and it is several times the steady state current. The inrush current results in a 15 percent under-voltage transient at the load's DC bus, with a return to steady state conditions in less than a millisecond. As shown in the figure, the steady state ripple at the load is approximately 5 percent at $10 \mathrm{kHz}$, primarily due to the unbalance in the 12 pulse rectification used for the alternator controller. When the system is operated with all user load, which eliminates the effect of the unbalance in the alternator control transformers, the load voltage ripple is only 0.5 percent. The only filter on the loads are $400 \mu \mathrm{sec}$ capacitive noise filters which are ineffective at the ripple frequency. These transient responses compare favorably with past results for similar load switching methods conducted at lower power levels (Hervol et al., 2004). 


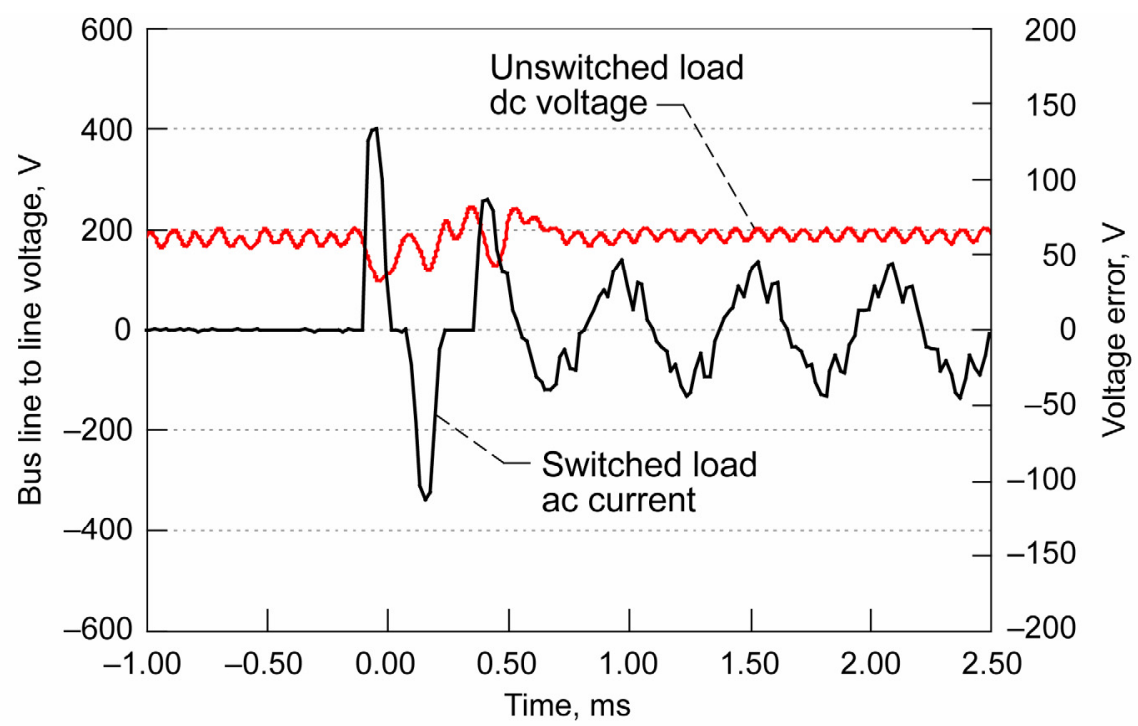

Figure 10.- Response in load A dc voltage and load B current during load-on condition.

\section{Conclusions}

This testing demonstrated some of the operational abilities of a permanent magnet alternator to provide 3-phase AC power to various loads employing a Wye-Delta transformer in combination with direct 12 pulse rectification of the power bus for user loads. It furthermore demonstrated the ability of a high power alternator control scheme based on shunt loading of the alternator output to successfully regulate output bus voltage and alternator shaft speed.

\section{References}

Baez, N.B., Birchenough, A.G., Lebron-Velilla, R.C., and Gonzalez, M.C., "Description of the Prometheus Program Alternator/Thruster Integration Laboratory (ATIL), ” NASA/TM-2005213895, NASA GRC, Cleveland, OH, 2005.

Hervol, D.S., Mason, L.S., and Birchenough, A., "Experimental Results from a $2 \mathrm{~kW}$ Brayton Power Conversion Unit," in proceedings of Space Technology and Applications International Forum (STAIF-2003), edited by M.S. El-Genk, AIP Conference Proceedings 665, Melville, NY, 2003, pp. 621-628.

Hervol, D.S., Mason, L.S., Birchenough, A., and Pinero, L., "Experimental Investigations From the Operation of a $2 \mathrm{~kW}$ Brayton Power Conversion Unit and a Xenon Ion Thruster," NASA/TM2004-212960, NASA GRC, Cleveland, OH, 2004. 


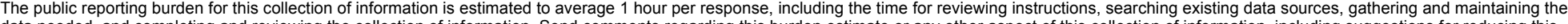

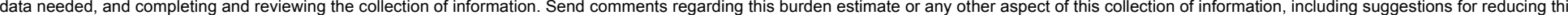

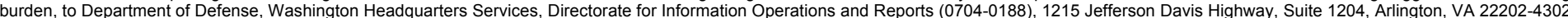

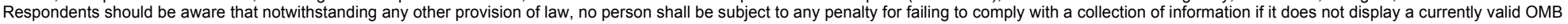
control number.

PLEASE DO NOT RETURN YOUR FORM TO THE ABOVE ADDRESS

\section{REPORT DATE (DD-MM-YYYY) \\ 2. REPORT TYPE \\ 3. DATES COVERED (From - To)}

05-01-2007

\section{TITLE AND SUBTITLE}

Technical Memorandum

Operational Results From a High Power Alternator Test Bed

5b. GRANT NUMBER

5c. PROGRAM ELEMENT NUMBER

\section{AUTHOR(S)}

Birchenough, Arthur; Hervol, David

\section{5d. PROJECT NUMBER}

5e. TASK NUMBER

5f. WORK UNIT NUMBER

WBS 463169.04.03

8. PERFORMING ORGANIZATION REPORT NUMBER

E-15933

National Aeronautics and Space Administration

John H. Glenn Research Center at Lewis Field

Cleveland, Ohio 44135-3191

\section{SPONSORING/MONITORING AGENCY NAME(S) AND ADDRESS(ES)}

National Aeronautics and Space Administration

Washington, DC 20546-0001

\section{SPONSORING/MONITORS ACRONYM(S) \\ NASA \\ 11. SPONSORING/MONITORING REPORT NUMBER \\ NASA/TM-2007-214708}

\section{DISTRIBUTION/AVAILABILITY STATEMENT}

Unclassified-Unlimited

Subject Categories: 20, 33, and 44

Available electronically at http://gltrs.grc.nasa.gov

This publication is available from the NASA Center for AeroSpace Information, 301-621-0390

\section{SUPPLEMENTARY NOTES}

\section{ABSTRACT}

The Alternator Test Unit (ATU) in the Lunar Power System Facility (LPSF) located at the NASA Glenn Research Center (GRC) in Cleveland, Ohio was used to simulate the operating conditions and evaluate the performance of the ATU and its interaction with various LPSF components in accordance with the current Fission Surface Power System (FSPS) requirements. The testing was carried out at the breadboard development level. These results successfully demonstrated excellent ATU power bus characteristics and rectified user load power quality during steady state and transient conditions. Information gained from this work could be used to assist the design and primary power quality considerations for a possible future FSPS. This paper describes the LPSF components and some preliminary test results.

\section{SUBJECT TERMS}

Brayton cycle; AC generators; Speed control; Electric power transmission

\begin{tabular}{|c|c|c|c|c|}
\hline \multicolumn{3}{|c|}{ 16. SECURITY CLASSIFICATION OF: } & \multirow{2}{*}{$\begin{array}{l}\text { 17. LIMITATION OF } \\
\text { ABSTRACT }\end{array}$} & \multirow{2}{*}{$\begin{array}{l}\text { 18. NUMBER } \\
\text { OF } \\
\text { PAGES } \\
14\end{array}$} \\
\hline $\begin{array}{l}\text { a. REPORT } \\
\text { U }\end{array}$ & $\begin{array}{l}\text { b. ABSTRACT } \\
\text { U }\end{array}$ & $\begin{array}{l}\text { c. THIS } \\
\text { PAGE } \\
\text { U }\end{array}$ & & \\
\hline
\end{tabular}

\begin{tabular}{l} 
19a. NAME OF RESPONSIBLE PERSON \\
David Hervol \\
\hline $\begin{array}{l}\text { 19b. TELEPHONE NUMBER (include area code) } \\
\text { 216-433-9624 }\end{array}$
\end{tabular}



